脳梗塞に対する薬物療法

一現状と問題点一

河野 浩之，平野 照之

杏林大学医学部脳卒中医学

\title{
Medical Therapy for Ischemic Stroke: Current State and Problems
}

\author{
Hiroyuki Kawano, M.D., Ph.D., and Teruyuki Hirano, M.D., Ph.D. \\ Department of Stroke and Cerebrovascular Medicine, Kyorin University
}

To prevent recurrent ischemic stroke in patients with non-valvular atrial fibrillation, it is recommended to start the administration of oral anticoagulants within 14 days of onset. In recurrent non-cardioembolic stroke cases, administration of dual antiplatelet therapy (clopidogrel plus aspirin for the first 21 days, followed by single antiplatelet therapy) can effectively reduce the risk of stroke recurrence and the risk of hemorrhage. The combination of cilostazol with aspirin or clopidogrel reduced the ischemic stroke recurrence and did not increase severe or life-threatening bleeding complications when compared with using aspirin or clopidogrel alone. For the treatment of patients with embolic stroke of undetermined sources (ESUS), direct oral anticoagulants were not superior to aspirin. ESUS may include underlying covert atrial fibrillation, patent foramen ovale, and aortogenic embolism. In emergencies, idarucizumab can rapidly reverse the anticoagulant effect of dabigatran. The four-factor prothrombin complex concentrate is not only effective, but also superior to plasma in the rapid reversal of the prothrombin time-international normalized ratio induced by vitamin $\mathrm{K}$ antagonists. After an ischemic stroke or transient ischemic attack in patients with atherosclerosis, the low target level of low-density lipoprotein of $<70 \mathrm{mg} / \mathrm{d} l$ is superior to the high target range of $90-110 \mathrm{mg} / \mathrm{d} l$ in preventing subsequent cardiovascular events. For patients with active cancer, anticoagulant therapy, including subcutaneous heparin injections, may be recommended.

(Received August 15, 2021 ; accepted September 16, 2020)

Key words : ischemic stroke, dual antiplatelet therapy, ESUS, PFO, LDL cholesterol

Jpn J Neurosurg（Tokyo） $30: 778^{-784, ~} 2021$

\section{はじめに}

脳梗塞の薬物療法は，抗血栓療法と危険因子の管理に 要約される。臨床病型に応じて, 心原性脳塞栓症に抗凝 固薬〔direct oral anticoagulants（DOAC）または用量調整

ワルファリン]，その他は抗血小板薬を選択する。血管危 険因子の管理については, LDL コレステロールを中心に
述べる.

\section{非弁膜症性心房細動に対する抗凝固療法}

「弁膜症性」とは「リウマチ性僧帽弁疾患（主に狭窄

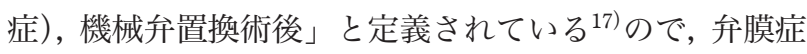
を伴わない心房細動が「非弁膜症性心房細動（non-val-

連絡先：河野浩之， $\overline{7} 181-8611$ 三鷹市新川 6-20-2 杏林大学医学部脳卒中医学

Address reprint requests to: Hiroyuki Kawano, M.D., Ph.D., Department of Stroke and Cerebrovascular Medicine, Kyorin University, 6-20-2 Shinkawa, Mitaka-shi, Tokyo 181-8611, Japan 
vular atrial fibrillation：NVAF)」である. 経口抗凝固薬の 名称は DOAC と non-vitamin K antagonist oral anticoagulants（NOAC）が存在するが，本稿では脳卒中治療がイ ドライン $2021^{19)}$ に倣い，DOAC と記載する。

脳梗塞再発予防を目的とした DOACやワルファリン の開始時期は, 脳梗塞発症後 2 週間以内が目安となって いる ${ }^{19)}$. しかし, DOACの有効性を証明した 4 つの無作 為化比較試験 ${ }^{5}$ (9) 12)22) では急性期脳梗塞を除外していた

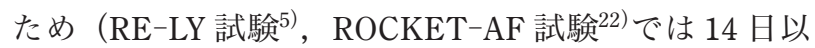
降, ARISTOTLE 試験 ${ }^{12)} て ゙ は 7$ 日以降, ENGAGE AF TIMI-48 試験 ${ }^{9}$ では 30 日以降に投薬), 適切な開始時期 は明確でなかった。

NVAF を有する, 発症 48 時間以内の急性期脳梗塞また は一過性脳虚血発作（transient ischemic attack：TIA）に 対してリバーロキサバンを投与した多施設共同前向き非 介入観察研究 RELAXED 試験が行われた ${ }^{38)}$ 。脳梗塞再発 割合は，15 日以降開始群と比較し，発症 14 日以内開始 群は有意に少なかった $(2.0 \%$ vs. $6.8 \%, \mathrm{p}=0.0034)$. 研 究全体では脳梗塞再発は $2.3 \%$, 大出血は $0.8 \%$ であっ た ${ }^{38)}$ ことから, 発症 14 日以内を抗凝固療法の開始の目安 とする考えを支持する結果であった，欧州の専門家の意 見「1-3-6-12 days ルール」33)では，DOAC の開始時期と して TIA は 1 日後, 軽症脳梗塞では 3 日後, 中等症では 6 日後, 重症では 12 日後からの開始を推奨している. NVAF を有する急性期脳梗塞/TIA の多施設共同前向き 観察研究 SAMURAI-NVAF では，軽症例（NIHSS 4 点以 下）では 3 日後，中等症例（NIHSS 5 14 点）では 4 日 後, 重症例（NIHSS 15 点以上）では 5 日後から開始さ れ ${ }^{34)}$ 「1-3-6-12 days ルール」33) より開始時期が早かっ た。その他, 複数の観察研究でも DOAC の早期開始を支 持する結果であった ${ }^{202} 21$ (1) 30)37)。ただし，登録例の多くは 軽症〜中等症であったことを考慮する必要がある。

現在, 心原性脳塞栓症急性期に対する DOAC の至適開 始時期を明らかにするための無作為化試験が複数進行中 である（ELAN, NCT03148457; OPTIMAS; START, NCT03021928; TIMING, NCT02961348など). 重症例や 大梗塞例に対する抗凝固療法については未解決である.

\section{非心原性脳梗塞に対する抗血小板薬併用療法}

抗血小板薬併用療法 (dual antiplatelet therapy: DAPT) は発症から 3 週間が目処である。根拠となっている論文 の 1 つが CHANCE 試験である ${ }^{36)}$.

CHANCE 試験では，発症 24 時間以内の軽症脳梗塞 (NIHSS 3 点以下) またはハイリスク TIA $\left(\mathrm{ABCD}^{2} 4\right.$ 点以
上）を，DAPT 群（初日にクロピドグレル $300 \mathrm{mg}$ とアス ピリン 75〜300 mg を投与, 2〜21 日目はクロピドグレル $75 \mathrm{mg}$ とアスピリン $75 \mathrm{mg}$ を併用，その後はクロピドグ レル $75 \mathrm{mg}$ 単剤) と, アスピリン単剤群に割り付けた ${ }^{36)}$. アスピリン単剤群と比較して DAPT 群で 90 日後脳卒中 の割合が有意に少なく（DAPT 群 $8.2 \% ，$ アスピリン群 $11.7 \%$ ，ハザード比 $0.68,95 \% \mathrm{CI} 0.57 \sim 0.81, \mathrm{p}<0.001)$ ， 出血は増加しなかった (各群 $0.3 \%, \mathrm{p}=0.73)^{36}$.

POINT 試験では，発症 12 時間以内の軽症脳梗塞 (NIHSS 3 点以下) またはハイリスク TIA $\left(\mathrm{ABCD}^{2} 4\right.$ 点以 上）を, DAPT 群（初日にクロピドグレル $600 \mathrm{mg}$ とアス ピリン 50〜325 mg を投与, 2〜90日目はクロピドグレル $75 \mathrm{mg}$ とアスピリン 50〜325 mg を併用) とアスピリン単 剂群に割り付けた ${ }^{15)}$ 。アスピリン群と比較し, DAPT 群 では 90 日後脳卒中・心筋梗塞・心血管死が減少したが （DAPT 群 5.0\%，アスピリン群 6.5\%，ハザード比 0.75 , $95 \%$ CI 0.59 0.95, p=0.02), 大出血が増加した（DAPT 群 $0.9 \%$, アスピリン群 $0.4 \%$, 八ザード比 $2.32,95 \% \mathrm{CI}$ $1.10 \sim 4.87, \mathrm{p}=0.02)^{15)}$. CHANCE 試験と POINT 試験の 結果から, DAPT の継続期間は 3 週間が目処と考える.

わが国で実施された CSPS.com 研究 ${ }^{35)}$ では, 発症 8〜 180 日の非心原性脳梗塞で, 頚部または頭蓋内動脈に $50 \%$ 以上の狭窄を有する，または 2 つ以上の動脈硬化危 険因子を有する症例を，シロスタゾールを含む DAPT 群 と，アスピリンもしくはクロピドグレルの抗血小板薬単 剤群に割り付けた。シロスタゾールを含む DAPT 群で は，症候性脳梗塞再発（DAPT 群 $2.2 \%$ /年，抗血小板薬 単剂群 $4.5 \%$ /年，ハザード比 $0.49,95 \%$ CI $0.31 〜 0.76$, $\mathrm{p}=0.0010)$ が少なく, 重大または致死的出血は増加しな かった (DAPT 群 $0.6 \%$ /年, 抗血小板薬単剂群 $0.9 \%$ /年, ハザード比 $0.66,95 \% \mathrm{CI} 0.27 \sim 1.60, \mathrm{p}=0.35)^{35)}$. 八イ リスクの非心原性脳梗塞に対してアスピリンまたはクロ ピドグレルにシロスタゾールを長期併用することは安全 ということが示された。

\section{新規薬剤による脳梗塞再発予防への期待}

DAPT でも脳梗塞を再発することがある (CHANCE 試 験 $7.9 \%{ }^{36)}$, POINT 試験 $4.6 \%{ }^{15)}$ ) . 現在, 新規の活性型 第XI因子阻害薬が開発中で，第 II 相試験が 2 つ進行中で ある (PACIFIC STROKE, AXIOMATIC-SSP)。活性型第 XI因子阻害薬は, トロンビンの生成・活性を阻害するこ とで血栓症は予防するが，内因系凝固因子のみを阻害す ることで出血を増加させないことが期待されている. 


\section{潜因性脳梗塞，塞栓源不明脳塞栓症}

脳梗塞の 3 大病型（ラクナ梗塞，アテローム血栓性脳 梗塞, 心原性脳塞栓症), その他の特定の原因による脳梗 塞（動脈解離, 血管炎, 抗リン脂質抗体症候群, もやも や病など）以外の，原因がはっきりしない脳梗塞は約 $25 \%$ を占めるとされ ${ }^{13)}$, 潜因性脳梗塞と呼ばれる。潜因 性脳梗塞の大部分は塞栓性という仮説に基づいて塞栓源 不明脳塞栓症 (embolic stroke of undetermined source: ESUS）が提唱された ${ }^{13)}$. Saver $ら^{28)}$ は潜因性脳梗塞にお ける重要な塞栓源として潜在性心房細動と卵円孔開存 (patent foramen ovale：PFO）を挙げている.

ESUS に対するNOAC の有効性と安全性をみるための 研究が発表された. NAVIGATE-ESUS 研究では, ESUS が対象で，リバーロキサバンとアスピリンに割り付け $た^{14)}$. 有効性 (脳梗塞再発, 出血性脳卒中, 全身塞栓症) ではリバーロキサバン群 $5.1 \%$ /年，アスピリン群 $4.8 \%$ / 年で, 有意差はなかった(ハザード比 $1.07,95 \% \mathrm{CI} 0.87$ $1.33, \mathrm{p}=0.52)$. 脳梗塞再発は両群とも $4.7 \% /$ 年で同等 であった。安全性（大出血）は，リバーロキサバン群 $1.8 \%$ / 年, アスピリン群 $0.7 \%$ / 年であり, リバーロキサ バン群で有意に多かった（ハザード比 $2.72,95 \% \mathrm{CI}$ 1.68 4.39, p<0.001 $)^{14)}$. RE-SPECT ESUS 研究では, ESUS が対象で，ダビガトランとアスピリンに割り付け $た^{8)}$. 有効性 (脳梗塞再発) ではダビガトラン群 $4.1 \%$ / 年，アスピリン群 $7.7 \%$ /年で有意差はなかった（ハザー ド比 $0.85,95 \% \mathrm{CI} 0.69 \sim 1.03, \mathrm{p}=0.10)$. 脳梗塞はダビ ガトラン群 $4.0 \%$ / 年, アスピリン群 $4.7 \%$ /年で有意差は なかった（ハザード比 $0.84 ， 95 \% \mathrm{CI} 0.68 〜 1.03)^{8}$ ). 安全 性（大出血）については, ダビガトラン群 $1.7 \%$ /年, ア スピリン群 $1.4 \%$ /年で有意差はなかった（ハザード比 $1.19,95 \% \mathrm{CI} 0.85 \sim 1.66)^{8)}$. 両研究とも, ESUS に対する DOAC は，アスピリンを上回る効果を認めなかった。単 にDOAC を投与するということは避けるべきである.

ESUS は個別化が必要で, 潜在性心房細動, PFO, 動 脈原性脳塞栓症など原因の特定が重要となる。

\section{潜在性心房細動の検出}

ESUS では潜在性心房細動の検出に注力する，通常の 検査ではみつかりにくい潜在性心房細動検出には，長時 間心電計モニタリングが有効である. CRYSTAL-AF研究 は, 24 時間以上の心電図モニタリングで心房細動を検出 できなかった発症 90 日以内の脳梗塞または TIA を植込 型心電計群と対照群（従来フォローアップ）に割り付け
た無作為化比較試験である ${ }^{26)}$ 。心房細動の検出率は 6 力 月時点で植込型心電計群 $8.9 \%$, 対照群 1.5\%（ハザード 比 6.4, 95\% CI 1.9 21.7, $\mathrm{p}<0.001), 12$ 力月時点で植込 型心電計群 $12.4 \%$ ，対照群 $2.0 \%$ （ハザード比 $7.3 ， 95 \%$ CI 2.6 20.8, p < 0.001)，36 力月時点で植込型心電計群 $30.0 \%$, 対照群 $3.0 \%$ (ハザード比 $8.8,95 \%$ CI 3.5〜22.2, $\mathrm{p}<0.001)$ であり, 植込型心電計で有意に心房細動の検 出率が高かった ${ }^{26)}$.

メ夕解析では，通常の心電図やホルター心電図だけで なく, 体外装着型心電計や植込型心電計を組み合わせる ことで，4 人に 1 人の割合 $(23.7 \% ， 95 \%$ CI 17.2〜31.0) で心房細動が検出された ${ }^{31)}$ 。一方で，約 7 割では心房細 動が検出されなかったということでもあり，ESUS に対 するDOACの有効性が示されなかった理由の 1 つかもし れない.

\section{卵円孔開存(PFO)に対する経皮的PFO閉鎖術}

2019 年に PFO が関与する潜因性脳梗塞に対する脳梗 塞再発予防を目的とした経皮的 $\mathrm{PFO}$ 閉鎖術の手引き ${ }^{18)}$ が発表され，また，PFO 閉鎖デバイスが保険収載され た. 本治療は 2017 年に発表された $3 つ の$ 研究で, 経皮的 PFO 閉鎖術において抗血小板薬群，または抗血小板薬を 含む薬物治療群に比して脳梗塞再発が有意に少なかった ことに基づいている ${ }^{16) 29} 32$. 治療対象は原則として 60 歳 未満の患者である。ラクナ梗塞やアテローム血栓性脳梗 塞ではなく，心房細動などの高リスク塞栓源心疾患がな いが塞栓性機序が考えられる場合には特に積極的に $\mathrm{PFO}$ を探すＰFOの診断には経食道心エコー検査が必要 だが，その前に，マイクロバブルを注入して行うコント ラスト経頭蓋超音波ドプラまたはコントラスト経胸壁心 エコーがスクリーニング検査として有用である。本治療 の重要な点は，(1)PFO を確実に診断する，(2)PFOを偶発 的に有する脳梗塞を除外する，(3深部静脈血栓症の有無 は必須ではない，(4)ブレインハートチーム（脳卒中学会 専門医, 循環器学会専門医, 心血管インターベンション 治療学会専門医で構成) で情報を共有し，有効性，安全 性，治療適応を考慮することである。

\section{抗凝固薬の拮抗薬}

抗凝固療法中の緊急手術や出血合併症は重大な問題で ある。ワルファリンに対してはプロトロンビン複合体製 剤 (4 F-PCC), ダビガトランに対してはイダルシズマブ を使用できる４ $4 \mathrm{~F}-\mathrm{PCC}$ は血液凝固第 II，第VII，第IX， 
第X因子を合わせた製剂である. ワルファリン投与によ り減少したこれらの凝固因子をすみやかに補充しワル ファリンの効果を中和する。 $4 \mathrm{~F}-\mathrm{PCC}$ は血漿投与と比較 してすみやかに PT-INR を低下できる ${ }^{1127)}$. 4 F-PCC 投 与時はビタミン $\mathrm{K}$ を併用投与する.

ダビガトランはイダルシズマブで中和できる，イダル シズマブはダビガトランに特異的に結合し, ダビガトラ ンの中和以外に凝固促進作用や凝固活性は示さないとさ れる。イダルシズマブはダビガトランをすみやかに中和 し，希釈トロンビン時間やエカリン凝固時間で評価した 4 時間以内の中和効果は $100 \%$ であった ${ }^{23)}$.

第 Xa 因子阻害薬の中和薬として, andexanet alfa ${ }^{6}$ があ り，米国では承認されているが，わが国では未承認であ る. Ciraparantag も開発中 ${ }^{3)}$ で, 現在は未承認である.

\section{積極的内科治療：LDL コレステロールの目標}

頭蓋内動脈狭窄によるTIA または脳梗塞に対して積極 的内科治療の成績がよかったことが SAMMPRIS 試験で 報告された ${ }^{4) 7)}$. 本試験では, 脂質低下療法は LDL コレ ステロール $70 \mathrm{mg} / \mathrm{d} l$ 未満に目標設定された。そのほか に, アスピリン $325 \mathrm{mg} /$ 日（追跡期間中）+クロピドグレ ル $75 \mathrm{mg} /$ 日 $(90$ 日間), 降圧治療〔目標収縮期血圧 $<140$ $\mathrm{mmHg}$ （糖尿病合併例は $<130 \mathrm{mmHg}$ ) ], 生活習慣介入 (糖尿病, 非 HDL コレステロール, 喫煙, 体重, 運動, カウンセリング）も行っていた.

動脈硬化を有する脳梗塞/TIAの再発予防の場合, LDL コレステロールの目標が 100 前後でよいのか, 70 未満が よいのかという疑問を明らかにする無作為化比較試験 Treat Stroke to Target が発表された ${ }^{21}$. 脳心血管動脈硬化 を有する, 発症 3 力月以内の脳梗塞または 15 日以内の TIA が対象で, $70 \mathrm{mg} / \mathrm{d} l$ 未満群と $90 \sim 110 \mathrm{mg} / \mathrm{d} l$ 群に割 り付けた。複合エンドポイント (脳梗塞, 心筋梗塞, 入 院を必要とする不安定狭心症で冠動脈形成術施行, 緊急 顼動脈血行再建が必要な $\mathrm{TIA}$, 心血管死）は $70 \mathrm{mg} / \mathrm{d} l$ 未 満群 $8.5 \%, 90 \sim 110 \mathrm{mg} / \mathrm{d} l$ 群 $10.9 \%$ で, $70 \mathrm{mg} / \mathrm{d} l$ 未満群 で有意に血管イベントが少なかった（補正ハザード比 $0.78,95 \%$ CI 0.61 0.98, p = 0.04, Fig. 1 $)^{2)}$. 本研究の結 果から, 動脈硬化を有する脳梗塞/TIA の再発予防の場 合, LDL コレステロールは $70 \mathrm{mg} / \mathrm{d} l$ 未満がよいと考え る.

スタチンだけでは LDL コレステロールが $70 \mathrm{mg} / \mathrm{d} l$ 未 満にならない場合, エゼチミブや PCSK9 阻害薬で低下 できる。動脈硬化ハイリスクでストロングスタチン投与 中の患者を PCSK9 阻害薬群とプラセボ群に割り付けた

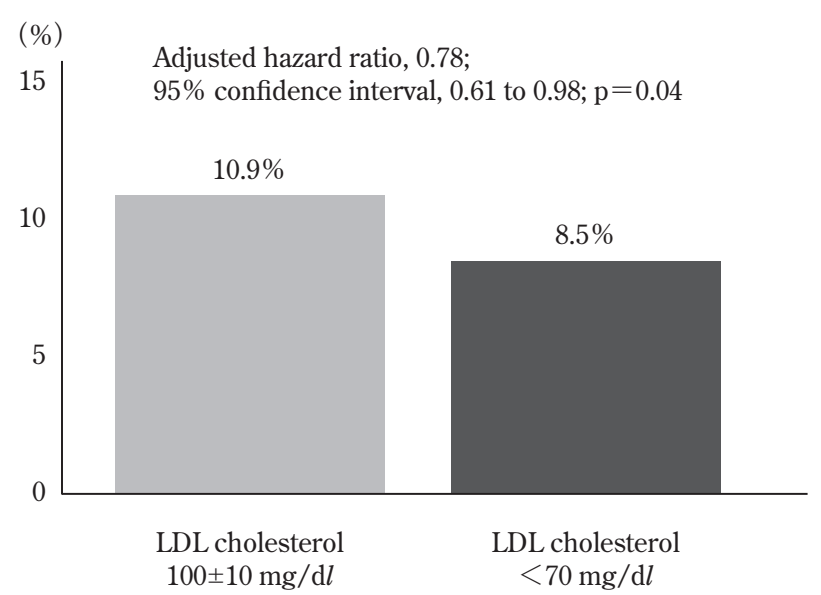

Fig. 1 Incidence of the composite primary endpoint of major cardiovascular events in the two groups

The major cardiovascular events included nonfatal cerebral infarction or stroke of undetermined origin, nonfatal myocardial infarction, hospitalization for unstable angina followed by urgent coronary-artery revascularization, transient ischemic attack treated with urgent carotid revascularization, or cardiovascular death including unexplained sudden death.(Fig. 1 has been created based on reference 2.)

ところ, PCSK9 阻害薬群では有意に LDL コレステロー ルが低下した〔最小二乗平均低下率は 59\%（95\%CI 58〜 $60, \mathrm{p}<0.001)$, 平均絶対低下は $56 \mathrm{mg} / \mathrm{d} l]^{25)}$. また, プ ラセボ群と比較し PCSK9 阻害薬群は, 全脳卒中（1.5\% vs. $1.9 \%$ ，ハザード比 $0.79,95 \% \mathrm{CI} 0.66 \sim 0.95, \mathrm{p}=0.01)$, 脳梗塞（1.2\% vs. $1.6 \%$ ，ハザード比 $0.75 ， 95 \%$ CI 0.62〜 $0.92, \mathrm{p}=0.005)$, 脳梗塞/TIA（1.7\% vs. $2.1 \%$, ハザード 比 $0.77,95 \% \mathrm{CI} 0.65 \sim 0.92, \mathrm{p}=0.003 ）$ が有意に少なく, 出血性脳卒中は増加しなかった $(0.21 \%$ vs. $0.18 \%$ ，八 ザード比 1.16, 95\%CI 0.68〜 1.98, p $=0.59)^{10)}$. 薬剤費 を考慮する必要はあるが, LDL コレステロール $70 \mathrm{mg} / \mathrm{d} l$ 未満, 脳梗塞など血管イベント減少という目標を考える と PCSK9 阻害薬は選択肢になり得る.

\section{がん関連脳梗塞}

脳卒中治療ガイドライン 2021 ${ }^{19)}$ では, がん関連脳梗塞 (トルソー症候群ともよばれる) には抗凝固療法を行うこ とを考慮するよう記載されている。低分子ヘパリンはわ が国では使いにくい.未分画へパリンは入院中であれば 持続点滴が可能である。退院後であれば，ヘパリンカル シウム皮下注は, 自己注射が保険適応となっているため 選択可能である。ワルファリンは薬物相互作用やビ夕ミ 
ン K 摂取量低下による PT-INR 過延長の問題を生じる. 活動性がんで静脈血栓塞栓症合併例への第 Xa 因子阻害 薬と低分子へパリンの無作為化比較試験では, 第Xa因 子阻害薬で静脈血栓塞栓症が少ない ${ }^{39)}$, または非劣 性 ${ }^{124)}$ と報告され, 出血は増加するという報告 ${ }^{2439)}$ と増 加しないという報告 ${ }^{1)}$ がある. がん関連脳梗塞で静脈血. 栓塞栓症合併例は静脈血栓塞栓症の再発予防目的の第 Xa 因子阻害薬は可能と考える。しかし, 主に動脈血栓症で ある脳梗塞に直接当てはめることは難しいと考える.

COI

著者全員は，自己申告による COI 報告書を日本脳神経外科 コングレス事務局に提出しています。

\section{文 献}

1) Agnelli G, Becattini C, Meyer G, Muñoz A, Huisman MV, Connors JM, Cohen A, Bauersachs R, Brenner B, Torbicki A, Sueiro MR, Lambert C, Gussoni G, Campanini M, Fontanella A, Vescovo G, Verso M ; Caravaggio Investigators: Apixaban for the treatment of venous thromboembolism associated with cancer. $N$ Engl J Med 382: 1599-1607, 2020.

2) Amarenco P, Kim JS, Labreuche J, Charles H, Abtan J, Béjot Y, Cabrejo L, Cha JK, Ducrocq G, Giroud M, Guidoux C, Hobeanu C, Kim YJ, Lapergue B, Lavallée PC, Lee BC, Lee KB, Leys D, Mahagne MH, Meseguer E, Nighoghossian N, Pico F, Samson Y, Sibon I, Steg PG, Sung SM, Touboul PJ, Touzé E, Varenne O, Vicaut É, Yelles N, Bruckert E ; Treat Stroke to Target Investigators : A comparison of two LDL cholesterol targets after ischemic stroke. $N$ Engl J Med $382: 9,2020$.

3) Ansell JE, Bakhru SH, Laulicht BE, Steiner SS, Grosso MA, Brown K, Dishy V, Lanz HJ, Mercuri MF, Noveck RJ, Costin JC: Single-dose ciraparantag safely and completely reverses anticoagulant effects of edoxaban. Thromb Haemost 117: 238-245, 2017.

4) Chimowitz MI, Lynn MJ, Derdeyn CP, Turan TN, Fiorella D, Lane BF, Janis LS, Lutsep HL, Barnwell SL, Waters MF, Hoh BL, Hourihane JM, Levy EI, Alexandrov AV, Harrigan MR, Chiu D, Klucznik RP, Clark JM, McDougall CG, Johnson MD, Pride GL Jr, Torbey MT, Zaidat OO, Rumboldt Z, Cloft HJ ; SAMMPRIS Trial Investigators: Stenting versus aggressive medical therapy for intracranial arterial stenosis. NEngl J Med 365 : 993-1003, 2011.

5) Connolly SJ, Ezekowitz MD, Yusuf S, Eikelboom J, Oldgren J, Parekh A, Pogue J, Reilly PA, Themeles E, Varrone J, Wang S, Alings M, Xavier D, Zhu J, Diaz R, Lewis BS, Darius H, Diener HC, Joyner CD, Wallentin L; RE-LY Steering Committee and Investigators: Dabigatran versus warfarin in patients with atrial fibrillation. $N$ Engl J Med 361 : 1139-1151, 2009.

6) Connolly SJ, Crowther M, Eikelboom JW, Gibson CM, Curnutte JT, Lawrence JH, Yue P, Bronson MD, Lu G, Conley PB, Verhamme P, Schmidt J, Middeldorp S, Cohen AT, Beyer-Westendorf J, Albaladejo P, Lopez-Sendon J, Demchuk AM, Pallin DJ, Concha M, Goodman S, Leeds J, Souza
S, Siegal DM, Zotova E, Meeks B, Ahmad S, Nakamya J, Milling TJ Jr; ANNEXA-4 Investigators : Full study report of Andexanet Alfa for bleeding associated with factor $\mathrm{Xa}$ inhibitors. N Engl J Med 380: 1326-1335, 2019.

7) Derdeyn CP, Chimowitz MI, Lynn MJ, Fiorella D, Turan TN, Janis LS, Montgomery J, Nizam A, Lane BF, Lutsep HL, Barnwell SL, Waters MF, Hoh BL, Hourihane JM, Levy EI, Alexandrov AV, Harrigan MR, Chiu D, Klucznik RP, Clark JM, McDougall CG, Johnson MD, Pride GL Jr, Lynch JR, Zaidat OO, Rumboldt $Z$, Cloft $\mathrm{HJ}$; Stenting and aggressive medical management for preventing recurrent stroke in intracranial stenosis trial investigators : Aggressive medical treatment with or without stenting in high-risk patients with intracranial artery stenosis (SAMMPRIS) : the final results of a randomised trial. Lancet $383: 333-341,2014$.

8) Diener HC, Sacco RL, Easton JD, Granger CB, Bernstein RA, Uchiyama S, Kreuzer J, Cronin L, Cotton D, Grauer C, Brueckmann M, Chernyatina M, Donnan G, Ferro JM, Grond M, Kallmünzer B, Krupinski J, Lee BC, Lemmens R, Masjuan J, Odinak M, Saver JL, Schellinger PD, Toni D, Toyoda K; RE-SPECT ESUS Steering Committee and Investigators: Dabigatran for prevention of stroke after embolic stroke of undetermined source. $N$ Engl J Med 380 : 1906-1917, 2019.

9) Giugliano RP, Ruff CT, Braunwald E, Murphy SA, Wiviott SD, Halperin JL, Waldo AL, Ezekowitz MD, Weitz JI, Špinar J, Ruzyllo W, Ruda M, Koretsune Y, Betcher J, Shi M, Grip LT, Patel SP, Patel I, Hanyok JJ, Mercuri M, Antman EM ; ENGAGE AF-TIMI 48 Investigators: Edoxaban versus warfarin in patients with atrial fibrillation. $N$ Engl J Med 369: 2093-2104, 2013.

10) Giugliano RP, Pedersen TR, Saver JL, Sever PS, Keech AC, Bohula EA, Murphy SA, Wasserman SM, Honarpour N, Wang H, Lira Pineda A, Sabatine MS ; FOURIER Investigators: Stroke Prevention with the PCSK9 (Proprotein Convertase Subtilisin-Kexin Type 9) Inhibitor Evolocumab added to statin in high-risk patients with stable atherosclerosis. Stroke 51: 1546-1554, 2020.

11) Goldstein JN, Refaai MA, Milling TJ Jr, Lewis B, GoldbergAlberts R, Hug BA, Sarode R: Four-factor prothrombin complex concentrate versus plasma for rapid vitamin $\mathrm{K}$ antagonist reversal in patients needing urgent surgical or invasive interventions : a phase $3 \mathrm{~b}$, open-label, non-inferiority, randomised trial. Lancet $385: 2077-2087,2015$.

12) Granger CB, Alexander JH, McMurray JJ, Lopes RD, Hylek EM, Hanna M, Al-Khalidi HR, Ansell J, Atar D, Avezum A, Bahit MC, Diaz R, Easton JD, Ezekowitz JA, Flaker G, Garcia D, Geraldes M, Gersh BJ, Golitsyn S, Goto S, Hermosillo AG, Hohnloser SH, Horowitz J, Mohan P, Jansky P, Lewis BS, Lopez-Sendon JL, Pais P, Parkhomenko A, Verheugt FW, Zhu J, Wallentin L; ARISTOTLE Committees and Investigators: Apixaban versus warfarin in patients with atrial fibrillation. N Engl J Med 365 : 981-992, 2011.

13) Hart RG, Diener HC, Coutts SB, Easton JD, Granger CB, O’Donnell MJ, Sacco RL, Connolly SJ ; Cryptogenic Stroke/ ESUS International Working Group : Embolic strokes of undetermined source: the case for a new clinical construct. Lancet Neurol $13:$ 429-438, 2014.

14) Hart RG, Sharma M, Mundl H, Kasner SE, Bangdiwala SI, Berkowitz SD, Swaminathan B, Lavados P, Wang Y, Wang Y, Davalos A, Shamalov N, Mikulik R, Cunha L, Lindgren A, Arauz A, Lang W, Czlonkowska A, Eckstein J, Gagliardi RJ, 
Amarenco P, Ameriso SF, Tatlisumak T, Veltkamp R, Hankey GJ, Toni D, Bereczki D, Uchiyama S, Ntaios G, Yoon BW, Brouns R, Endres M, Muir KW, Bornstein N, Ozturk S, O' Donnell MJ, De Vries Basson MM, Pare G, Pater C, Kirsch B, Sheridan P, Peters G, Weitz JI, Peacock WF, Shoamanesh A, Benavente OR, Joyner C, Themeles E, Connolly SJ ; NAVIGATE ESUS Investigators : Rivaroxaban for stroke prevention after embolic stroke of undetermined source. $N$ Engl J Med 378:2191-2201, 2018.

15) Johnston SC, Easton JD, Farrant M, Barsan W, Conwit RA, Elm JJ, Kim AS, Lindblad AS, Palesch YY ; Clinical Research Collaboration, Neurological Emergencies Treatment Trials Network, and the POINT Investigators : Clopidogrel and aspirin in acute ischemic stroke and high-risk TIA. $N$ Engl J Med 379:215-225, 2018.

16) Mas JL, Derumeaux G, Guillon B, Massardier E, Hosseini H, Mechtouff L, Arquizan C, Béjot Y, Vuillier F, Detante O, Guidoux C, Canaple S, Vaduva C, Dequatre-Ponchelle N, Sibon I, Garnier P, Ferrier A, Timsit S, Robinet-Borgomano E, Sablot D, Lacour JC, Zuber M, Favrole P, Pinel JF, Apoil M, Reiner P, Lefebvre C, Guérin P, Piot C, Rossi R, Dubois ${ }^{-}$ Randé JL, Eicher JC, Meneveau N, Lusson JR, Bertrand B, Schleich JM, Godart F, Thambo JB, Leborgne L, Michel P, Pierard L, Turc G, Barthelet M, Charles-Nelson A, Weimar C, Moulin T, Juliard JM, Chatellier G ; CLOSE Investigators: Patent foramen ovale closure or anticoagulation vs. antiplatelets after stroke. N Engl J Med 377 : 1011-1021, 2017.

17）日本循環器学会/日本不整脈心電学会合同ガイドライン 2020 年改訂版不整脈薬物治療ガイドライン. https:// www.j-circ.or.jp/cms/wp-content/uploads/2020/01/JCS2020_ Ono200619.pdf（閲覧 2020 年 9 月）

18）日本脳卒中学会, 日本循環器学会, 日本心血管インター ベンション治療学会, 三学会合同手引き作成委員会：潜 因性脳梗塞に対する経皮的卵円孔開存閉鎖術の手引き. 脳卒中 $41: 417-441,2019$.

19）日本脳卒中学会, 脳卒中ガイドライン委員会: 脳卒中治 療ガイドライン 2021. 東京, 協和企画, 2021.

20) Paciaroni M, Agnelli G, Falocci N, Caso V, Becattini C, Marcheselli S, Rueckert C, Pezzini A, Poli L, Padovani A, Csiba L, Szabó L, Sohn SI, Tassinari T, Abdul-Rahim AH, Michel P, Cordier M, Vanacker P, Remillard S, Alberti A, Venti M, Scoditti U, Denti L, Orlandi G, Chiti A, Gialdini G, Bovi P, Carletti M, Rigatelli A, Putaala J, Tatlisumak T, Masotti L, Lorenzini G, Tassi R, Guideri F, Martini G, Tsivgoulis G, Vadikolias K, Liantinioti C, Corea F, Del Sette M, Ageno W, De Lodovici ML, Bono G, Baldi A, D’Anna S, Sacco S, Carolei A, Tiseo C, Acciarresi M, D’Amore C, Imberti D, Zabzuni D, Doronin B, Volodina V, Consoli D, Galati F, Pieroni A, Toni D, Monaco S, Baronello MM, Barlinn K, Pallesen LP, Kepplinger J, Bodechtel U, Gerber J, Deleu D, Melikyan G, Ibrahim F, Akhtar N, Mosconi MG, Bubba V, Silvestri I, Lees KR : Early recurrence and cerebral bleeding in patients with acute ischemic stroke and atrial fibrillation: Effect of anticoagulation and its timing: The RAF Study. Stroke $\quad 46: 2175-2182,2015$.

21) Paciaroni M, Agnelli G, Falocci N, Tsivgoulis G, Vadikolias K, Liantinioti C, Chondrogianni M, Bovi P, Carletti M, Cappellari M, Zedde M, Ntaios G, Karagkiozi E, Athanasakis G, Makaritsis K, Silvestrelli G, Lanari A, Ciccone A, Putaala J, Tomppo L, Tatlisumak T, Abdul-Rahim AH, Lees KR, Alberti A, Venti M, Acciarresi M, D’Amore C, Becattini C,
Mosconi MG, Cimini LA, Soloperto R, Masotti L, Vannucchi V, Lorenzini G, Tassi R, Guideri F, Acampa M, Martini G, Sohn SI, Marcheselli S, Mumoli N, De Lodovici ML, Bono G, Furie KL, Tadi P, Yaghi S, Toni D, Letteri F, Tassinari T, Kargiotis O, Lotti EM, Flomin Y, Mancuso M, Maccarrone M, Giannini N, Bandini F, Pezzini A, Poli L, Padovani A, Scoditti U, Denti L, Consoli D, Galati F, Sacco S, Carolei A, Tiseo C, Gourbali V, Orlandi G, Giuntini M, Chiti A, Giorli E, Gialdini G, Corea F, Ageno W, Bellesini M, Colombo G, Monaco S, Maimone Baronello M, Karapanayiotides T, Caso $\mathrm{V}$ : Early recurrence and major bleeding in patients with acute ischemic stroke and atrial fibrillation treated with non-vitamin-K oral anticoagulants (RAF-NOACs) Study.J Am Heart Assoc $\quad$ 6: e007034, 2017.

22) Patel MR, Mahaffey KW, Garg J, Pan G, Singer DE, Hacke W, Breithardt G, Halperin JL, Hankey GJ, Piccini JP, Becker RC, Nessel CC, Paolini JF, Berkowitz SD, Fox KA, Califf $\mathrm{RM}$; ROCKET AF Investigators : Rivaroxaban versus warfarin in nonvalvular atrial fibrillation. $N$ Engl J Med 365 : 883-891, 2011.

23) Pollack CV Jr, Reilly PA, van Ryn J, Eikelboom JW, Glund S, Bernstein RA, Dubiel R, Huisman MV, Hylek EM, Kam CW, Kamphuisen PW, Kreuzer J, Levy JH, Royle G, Sellke FW, Stangier J, Steiner T, Verhamme P, Wang B, Young L, Weitz $\mathrm{JI}$ : Idarucizumab for dabigatran reversal - full cohort analysis. NEngl J Med 377 : 431-441, 2017.

24) Raskob GE, van Es N, Verhamme P, Carrier M, Di Nisio M, Garcia D, Grosso MA, Kakkar AK, Kovacs MJ, Mercuri MF, Meyer G, Segers A, Shi M, Wang TF, Yeo E, Zhang G, Zwicker JI, Weitz JI, Büller HR ; Hokusai VTE Cancer Investigators : Edoxaban for the treatment of cancer-associated venous thromboembolism. N Engl J Med $\quad 378: 615^{-}$ 624, 2018.

25) Sabatine MS, Giugliano RP, Keech AC, Honarpour N, Wiviott SD, Murphy SA, Kuder JF, Wang H, Liu T, Wasserman SM, Sever PS, Pedersen TR; FOURIER Steering Committee and Investigators: Evolocumab and clinical outcomes in patients with cardiovascular disease. $N$ Engl J Med $\mathbf{3 7 6}$ : 1713-1722, 2017.

26) Sanna T, Diener HC, Passman RS, Di Lazzaro V, Bernstein RA, Morillo CA, Rymer MM, Thijs V, Rogers T, Beckers F, Lindborg K, Brachmann J ; CRYSTAL AF Investigators : Cryptogenic stroke and underlying atrial fibrillation. $\mathrm{N} \mathrm{Engl}$ J Med 370 : 2478-2486, 2014.

27) Sarode R, Milling TJ Jr, Refaai MA, Mangione A, Schneider A, Durn BL, Goldstein JN : Efficacy and safety of a 4-factor prothrombin complex concentrate in patients on vitamin $\mathrm{K}$ antagonists presenting with major bleeding : a randomized, plasma-controlled, phase IIIb study. Circulation 128: 1234-1243, 2013.

28) Saver JL : CLINICAL PRACTICE. Cryptogenic stroke. $N$ Engl J Med 374:2065-2074, 2016.

29) Saver JL, Carroll JD, Thaler DE, Smalling RW, MacDonald LA, Marks DS, Tirschwell DL; RESPECT Investigators: Long-term outcomes of patent foramen ovale closure or medical therapy after stroke. N Engl J Med 377 : 10221032, 2017.

30) Seiffge DJ, Traenka C, Polymeris A, Hert L, Peters N, Lyrer P, Engelter ST, Bonati LH, De Marchis GM : Early start of DOAC after ischemic stroke: Risk of intracranial hemorrhage and recurrent events. Neurology $\quad 87:$ 1856-1862, 2016 . 
31) Sposato LA, Cipriano LE, Saposnik G, Ruíz Vargas E, Riccio PM, Hachinski V : Diagnosis of atrial fibrillation after stroke and transient ischaemic attack: a systematic review and meta-analysis. Lancet Neurol 14:377-387, 2015.

32) Søndergaard L, Kasner SE, Rhodes JF, Andersen G, Iversen HK, Nielsen-Kudsk JE, Settergren M, Sjöstrand C, Roine RO, Hildick-Smith D, Spence JD, Thomassen L; Gore REDUCE Clinical Study Investigators : Patent foramen ovale closure or antiplatelet therapy for cryptogenic stroke. N Engl J Med 377 : 1033-1042, 2017.

33) Steffel J, Verhamme P, Potpara TS, Albaladejo P, Antz M, Desteghe L, Haeusler KG, Oldgren J, Reinecke H, RoldanSchilling V, Rowell N, Sinnaeve P, Collins R, Camm AJ, Heidbüchel H ; ESC Scientific Document Group: The 2018 European heart rhythm association practical guide on the use of non-vitamin $\mathrm{K}$ antagonist oral anticoagulants in patients with atrial fibrillation. Eur HeartJ $\mathbf{3 9}: 1330-1393$, 2018.

34) Toyoda K, Arihiro S, Todo K, Yamagami H, Kimura K, Furui E, Terasaki T, Shiokawa Y, Kamiyama K, Takizawa S, Okuda S, Okada Y, Kameda T, Nagakane Y, Hasegawa Y, Mochizuki H, Ito Y, Nakashima T, Takamatsu K, Nishiyama K, Kario K, Sato S, Koga M ; SAMURAI Study Investigators : Trends in oral anticoagulant choice for acute stroke patients with nonvalvular atrial fibrillation in Japan : the SAMURAI-NVAF study. Int J Stroke $10: 836-842,2015$.

35) Toyoda K, Uchiyama S, Yamaguchi T, Easton JD, Kimura K, Hoshino H, Sakai N, Okada Y, Tanaka K, Origasa H, Naritomi H, Houkin K, Yamaguchi K, Isobe M, Minematsu K ; CSPS.com Trial Investigators: Dual antiplatelet therapy using cilostazol for secondary prevention in patients with high-risk ischaemic stroke in Japan : a multicentre, openlabel, randomised controlled trial. Lancet Neurol $\quad 18: 539$ 548, 2019.

36) Wang Y, Wang Y, Zhao X, Liu L, Wang D, Wang C, Wang C, Li H, Meng X, Cui L, Jia J, Dong Q, Xu A, Zeng J, Li Y, Wang Z, Xia H, Johnston SC ; CHANCE Investigators : Clopidogrel with aspirin in acute minor stroke or transient ischemic attack. N Engl J Med 369: 11-19, 2013.

37) Wilson D, Ambler G, Banerjee G, Shakeshaft C, Cohen H, Yousry TA, Al-Shahi Salman R, Lip GYH, Houlden H, Brown MM, Muir KW, Jäger HR, Werring DJ ; Clinical relevance of Microbleeds in Stroke (CROMIS-2) collaborators : Early versus late anticoagulation for ischaemic stroke associated with atrial fibrillation: multicentre cohort study. $J$ Neurol Neurosurg Psychiatry 90 : 320-325, 2019.

38) Yasaka M, Minematsu K, Toyoda K, Mori E, Hirano T, Hamasaki T, Yamagami H, Nagao T, Yoshimura S, Uchiyama S ; RELAXED study group: Rivaroxaban administration after acute ischemic stroke: The RELAXED study. PLoS One 14: e0212354, 2019.

39) Young AM, Marshall A, Thirlwall J, Chapman O, Lokare A, Hill C, Hale D, Dunn JA, Lyman GH, Hutchinson C, MacCallum P, Kakkar A, Hobbs FDR, Petrou S, Dale J, Poole CJ, Maraveyas A, Levine $\mathrm{M}$ : Comparison of an oral factor Xa inhibitor with low molecular weight heparin in patients with cancer with venous thromboembolism : results of a randomized trial (SELECT-D). J Clin Oncol 36:2017-2023, 2018.

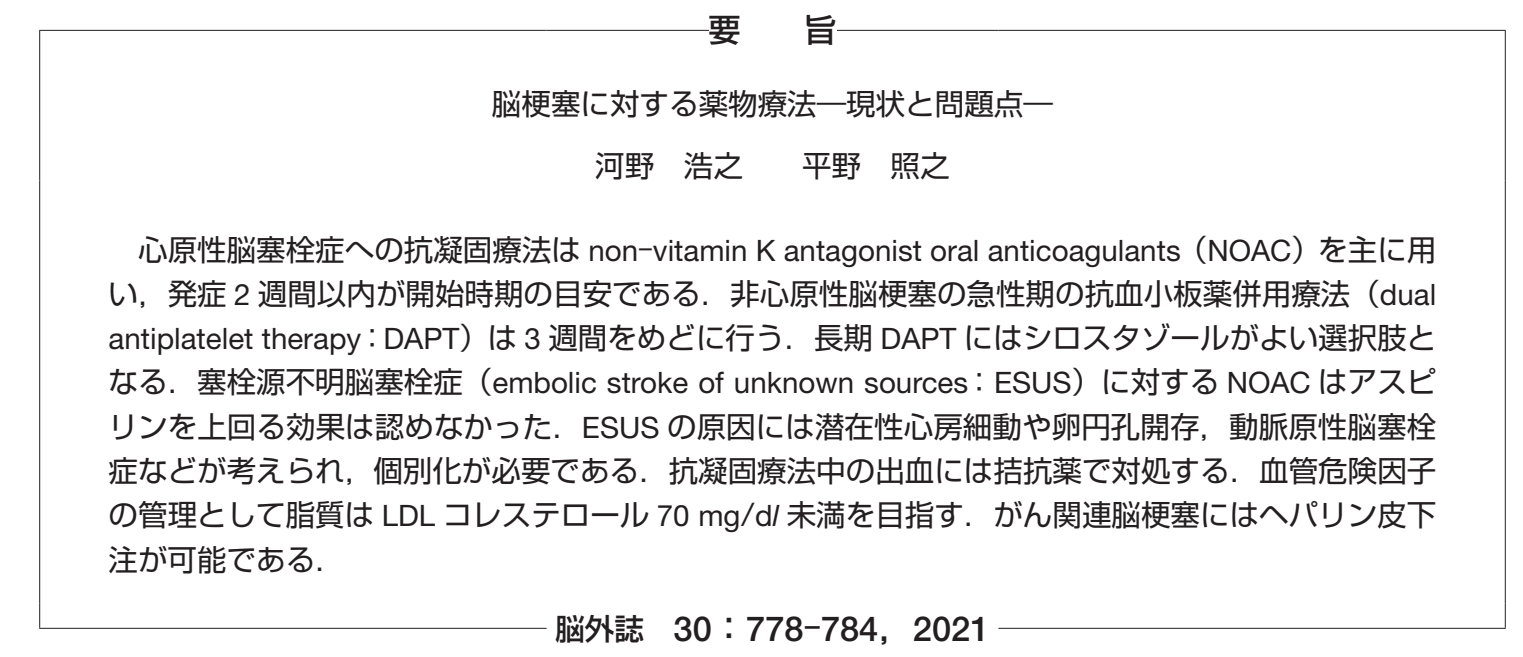

